\title{
The Impact of Joint Audit on Fraud Detection in Financial Statements From the Point of View of Auditors
}

\author{
Ola Muhammad Khersiat ${ }^{1}$ \\ ${ }^{1}$ Department of Accounting, Faculty of Economics and Administration Sciences, Zarqa University, Jordan \\ Correspondence: Dr Ola Mohammad Khersiat, Department of Accounting, Zarqa University, P.O. P. O. Box 132222, \\ Zarqa 13110, Jordan. Tel: 962-779-069-109. E-mail: ola_khersiat_1978@yahoo.com
}

Received: January 24, 2020

Accepted: February 24, 2020

Online Published: March 9, 2020

doi:10.5430/rwe.v11n1p153

URL: https://doi.org/10.5430/rwe.v11n1p153

\begin{abstract}
This study aimed to identify the application of joint audits to the detection of fraud in financial statements as well as the impact of joint audits on the detection of fraud in financial statements from the point of view of Jordanian auditors. The study focused on investigating the impact of joint audits of the procedures of understanding management and the board of directors, as well as examining the relationship with the relevant parties, the company and financial industry, financial results and operational characteristics in order to identify the impact of joint audits on detecting fraud in financial statements through these procedures. Results indicate that there is no statistically significant impact of joint audits on the detection of fraud in the financial statements at the level of $(5 \%)$ for all fraud detecting procedures in the financial statements. The study recommends not adopting or applying joint audit.
\end{abstract}

Keywords: joint audit, financial statements, fraud, financial results and operational processes

\section{Introduction}

Auditing is considered an organized, planned and logical operation carried out by professional and regulatory bodies. It follows organized procedures and steps that develop from international audit standards, where it ensures that all operations and processes presented and disclosed conform with the financial reporting standards, international accounting standards and accounting principles generally accepted, thus making sure of these operations and processes validity and impeccability and that they have been tested and verified in a way that preserves the company`s assets and continuity. Auditing presents results to reports and financial statement users and provides high-quality and objective services that have a positive impact on the users of auditor`s reports.

Several previous studies, namely: (Asare and Wright, 2004; Carpenter, 2007; Fernando et al., 2010; Porter et al., 2014) indicated that there is reasonable confirmation that in case any substantial misrepresentations resulting from any error or fraud are contained in financial statements, it is the responsibility of the auditor to detect and disclose these to reports and financial statements users as well as to the company management. The approval of the auditor and his loyalty regarding the detection and disclosure of substantial deliberate and non-deliberate misinterpretations and errors benefit and raise confidence in audit services provided by auditors, thus having a positive impact on their efforts to achieve their objectives.

The international standard of audit (ISA No. 240) indicates that the auditor should inform the management and officials about substantial fragility in the internal control system design and application to prevent and detect any manipulation in financial statements at the right time. The ISA has also assured that the auditor shall discuss any manipulation- related issues such as the failure of the management in confronting the substantial fragility in the appropriate internal control as well as responding appropriately to any manipulation in financial statements. In addition, the Standard evaluates the control environment to the assessment of the Unit's control environment in relation to inquiring about the management's reputation and administrative practices and integrity which might indicate a misinterpretation in financial statements, where the management would choose and apply accounting policies reflecting an attempt to manipulate financial statements through profit administration to mislead financial statement users by influencing their own judgment about the company`s profitability and performance (AICPA, 2017). 
The Jordanian Companies Act No. (34) For 2017, and the Legal Accounting Regulatory Act under the provisional law No. (73) for 2003, confirmed that the auditor bears responsibility of planning and executing the auditing process through professional skepticism in accordance with applied audit regulations and profession`s requirements. The auditor shall also do his best professional effort to ensure that financial statements do not contain any misinterpretations resulting from error or manipulation, and that the statements compiled and audit proceedings done for the company are deemed sufficient and appropriate to present a point of view of the financial statements in accordance with international audit standards. The two Acts mentioned above also confirmed that the auditor shall report to the management regarding any manipulation detected as soon as possible, as well as regarding substantial fragility in the design and application of the internal control system so as to detect and prevent any manipulation especially such that may have a substantial impact on the company`s business results and financial status. The auditor has the faculty not to endorse the statements, rather return these to the board of directors while explaining the reasons for such an act. In case of manipulation by the company`s senior management, the auditor shall get legal consultation to assist them in defining the proper procedures to be taken while taking into account confidentiality regarding manipulation unless stated otherwise by law or legislation. In case the management refuses to amend, the auditor shall prepare an inverse report regarding the statements where they provide substantial reasons for such a point of view.

Following the bankruptcy and collapse of major global auditing firms as Enron and World Com, the role of auditors was weakened by their failure to disclose the accounting information facts contained in financial reports, widening the gap between public expectations of auditors and what auditors actually do (Hijazi et al., 2016). Because many users rely on audited financial statements, the auditor shall be free from any pressure.On the other hand, in 2018, nine auditors in Jordan were dismissed due to manipulation in issuing financial audit reports for companies ' budgets for three previous years from 2015 to 2017. Moreover, an auditor's license was cancelled in 2019 due to manipulation in financial statements. The Income and Sales Tax Department in Jordan is re-auditing more than 1000 budgets, since the Department is suspicious of the existence of tax evasion worth millions of dinars in the budgets submitted fictitiously. Some of these budgets were audited by people who passed off as chartered accountants, or the chartered auditors` signatures were forged or manipulated by companies, institutions and stores."The Department is still tracking audit operations of a large number of companies` budgets that were fictitiously audited and where the Department suspects the existence of tax evasion." As confirmed by the head of the Jordanian Auditors Association that many companies refer their accounts to accountants rather than auditors (chartered accountants), which leads to problems with the tax, indicating that there are forgery cases of auditors` signatures and other cases of attributing a chartered accountant identity to themselves. The head of the Auditors` Association called companies or payers in general to enter into a clear annual contract that protects all parties when coming into a concord with the auditor. He suggested adding a term to the Companies Act stating that two auditors shall be elected instead of one and from different audit offices to audit public shareholdings` data (www.alghad.com, 28/11/2019). This is what is known as joint audit, which is performed by two or more auditors representing separate audit firms to carry out audit proceedings of financial data. A joint audit plan and joint performance is set to perform audit operations, and a joint report is issued signed by auditors. Therefore, this study is of importance to investigate the impact of joint audit on detecting fraud in financial statements from the point of view of auditors.

\section{Literature Review}

Krait, et.al (2017) aims to investigate the methods, principles and stages of joint audits in financial statements to complete audit procedures with the required efficiency and effectiveness. The study concluded that joint audit has an impact on improving risks assessment, particularly in relation to audit procedures and strategies, as well as taking joint resolutions regarding the audit process. It also has an impact on the accuracy of the assessment of control risks, particularly planning audit operations as well as the auditor`s estimations of the probability of substantial errors that cannot be detected by the company`s internal control. Moreover, it has an impact on the accuracy of assessing detection risks that were not detected by the internal control in a certain account or a number of accounts, whether in the analytical proceedings or details tests.

Kermiche, Piot (2018) used Markovian analysis where they chose their sample from auditors at Big4 and among junior auditors. The study concluded that the French joint audit system is effective in maintaining market openness and reducing the long-term dominance of Big 4.

Many studies have focused on the relationship between audit quality and costs, namely Haak, et,al (2018) which focused on the quality of joint audits and costs. The study concluded that individual audit may lead to an increase in audit quality and a decrease in audit fees compared to joint audit operations. Andre et al. (2016) addressed the 
relationship between audit quality and associated expenses. The European Commission`s proposal issued in 2010 stated that joint audit operations aim to improve the audit market. Whereas many parties see that joint audit operations are not considered an effective solution since, the joint audit quality may not commensurate with the paid fees. The study compared the audit fees from 2007 till 2011 paid by listed French companies from one side and Italian and British companies from the other. It is found that the audit fees paid by France are higher after it has controlled auditor and client's characteristics and proper documentation which differ from one country to another. The study concluded that there are no statistically significant differences in the size of non-natural audit revenues in France, because this does not mean that high audit fees are connected to a high quality of audit operations. Ittonen, et.al (2015) has concluded that when two auditors come from the same office, the efficiency of the audit process is higher, whereas when two auditors come from different offices, the audit process efficiency is higher compared to audit carried out by one auditor. The study also concluded that audit results do not vary whether the two auditors come from the same audit office or from different offices. Moreover, increases in costs are not shown to clients. Holm, et.al, (2016) concluded that joint audit has fixed coordination costs. However, in joint audit operations, whether small or large, there are higher audit fees when there is a share less than $25 \%$ to small audit firms.

Krait, et.al (2018) concluded that joint audit has a role in raising efficiency in the use of the characteristics significance, particularly assessing joint audit results test, as well as a role in the use of the variables significance in the audit operation, particularly the relative significance. It also has a role in identifying the size of the sample and the affecting factors, particularly the jointly acceptable risk rate. Moreover, it has a role in statistical significance regarding decreasing its use risks in audit; especially that audit operation is divided between joint auditors according to courses or jobs as applied by the firm.

Zerni, et. al (2012) concluded that companies that choose joint audit better preserve their profits, lower receivables, better credit rating and lower risk of bankruptcy compared to other companies. Moreover, results indicated that companies which apply joint audit bear higher fees, as well as this type of audit is positively associated to audit quality.

Alfaraih, et.al, (2012) indicated that the mandatory disclosure average level of all companies listed in Kuwait Stock Exchange in 2006 amounted to 72.6; indicating that they did not comply with the requirements of the mandatory disclosure due to the fact that they are bound to audit from two different external audit firms since 1995. It is indicated that the mandatory disclosure level in 1994 was $75 \%$ and $78 \%$ in 2006, with an increase amounting to 4\% in a period of 12 years. The results obtained in this study have a direct impact on the efficiency of mandatory disclosure in boosting companies' disclosure quality. Results show that noncompliance to mandatory disclosure requires two external auditors or may raise questions about quality and reliability.

Bianchi, et. al (2019) indicated that in the Italian audit system three individual auditors appointed by the same firm or different firms collaboratively and frequently review annual financial data for each client as well as signing tax returns. The study also concluded that the joint audit environment (the professional network) has an effect in tax results.

Deng, et. al (2012) conducted a comparison between the joint audit and individual audit. It concluded that individual audit provides more high quality evidence than joint audit. The study recommended not adopting or applying joint audit while relying more on the individual audit since there is a probability that one auditor may rely on another auditor in the audit process.

\section{Study's Advantage}

This study aimed to identify the application of joint audits to the detection of fraud in financial statements as well as the impact of joint audits on the detection of fraud in financial statements from the point of view of Jordanian auditors and the study focused on investigating the impact of joint audits of the procedures of understanding management and the board of directors, as well as examining the relationship with the relevant parties, the company and financial industry, financial results and operational characteristics in order to identify the impact of joint audits on detecting fraud in financial statements and Several previous studies focused on the quality of joint audits and costs, and comparison between the joint audit and individual audit in the audit process.

\section{Statistical Analysis and Hypothesis Testing}

The study is based on one main hypothesis and four sub-hypotheses:

Main hypothesis H0: there is no statistically significant impact of the impact of joint audit on detecting fraud in financial statements. 
Sub-hypotheses:

H01: there is no statistically significant impact of joint audit on the management and board of directors understanding to detect fraud in financial statements.

H02: there is no statistically significant impact of joint audit on the relationship with relevant parties to detect fraud in financial statements.

HO3: there is no statistically significant impact of joint audit on the company and financial industry to detect manipulation in financial statements.

HO4: there is no statistically significant impact of joint audit on the financial results and operational characteristics to detect fraud in financial statements.

The statistical analysis SPSS was used to drive results and test hypotheses. The internal consistency reliability in the questionnaire statements was tested and submitted to Cronbach Alpha test to drive consistency evaluation and correlation among the statements of the questionnaire amounting to (0.84), which is considered acceptable to rely on the results of the study. The questionnaire comprised two axes; the first axis contains 69 questions and the second 16 questions in order to investigate the impact of joint audits on the detection of fraud in the financial statements from the point of view of Jordanian auditors.

The study sample`s responses to the study statements were analyzed and discussed in the light of the study questions and hypotheses by relying on the arithmetic mean and standard deviation to investigate the significance of the statement in relation to describing the study sample responses to the questionnaire statements.

To answer the first question of the study, the arithmetic mean and the standard deviation of the study sample respondents` responses were calculated at Jordanian audit offices to identify the range of dispersion of the study sample responses from their arithmetic mean. Results of the arithmetic mean and standard deviation of each financial statements fraud detection proceeding were as follows:

Is there an impact of joint audit on the management and board of directors to detect fraud in financial statements?

Table 1. Statement (Understanding of the management and the board of directors)

\begin{tabular}{lccc}
\hline $\begin{array}{l}\text { Statement (Understanding of the management and the board of } \\
\text { directors) }\end{array}$ & $\begin{array}{c}\text { Arithmetic } \\
\text { mean }\end{array}$ & $\begin{array}{c}\text { Standard } \\
\text { deviation }\end{array}$ & Order \\
\hline $\begin{array}{l}\text { A joint audit ensures that the administration gets incentives for } \\
\text { manipulating revenue cuts for tax evasion purposes. }\end{array}$ & 4.29 & 0.45 & 1 \\
\hline $\begin{array}{l}\text { Joint audit ensures that maintaining the company's stock price } \\
\text { or increasing its value is in the interests of the management. }\end{array}$ & 1.19 & 0.39 & 24 \\
\hline $\begin{array}{l}\text { Joint audit investigates the holding of the personal assets of the } \\
\text { company's top managers }\end{array}$ & 1.19 & 0.39 & 24 \\
\hline All statements & 4.0833 & .77553 & \\
\hline
\end{tabular}

Results in Table 1 show that the general arithmetic mean of the management and managers statement reached (4.0833) and a standard deviation of (.77553), where it's bigger than the test criteria of (3) out of (5) degrees. The overall level of the study sample respondents` responses was high and positive.

The statement stating that " joint audit is based on ensuring that the management gets incentives as a result of manipulating revenues decrease for the purpose of tax evasion" ranked first in the study sample respondents` priorities and interests with an arithmetic mean of (4.29) and standard deviation of (0.45), while the statements stating that "joint audit ensures maintaining the company`s share price or raising its value as an interest of the management" and "joint audit investigates on the confinement of the company`s chief directors` personal wealth" came last in the study sample respondents 'interests with an arithmetic mean of (1.19) and standard deviation (0.39). Results mentioned in the table above indicate that there is an impact of joint audit on each statement of the management and board of directors`statements. 
Table 2. Statement (relationship with relevant parties)

\begin{tabular}{|c|c|c|c|}
\hline Statement (relationship with relevant parties) & $\begin{array}{l}\text { Arithmetic } \\
\text { mean }\end{array}$ & $\begin{array}{l}\text { Standard } \\
\text { deviation }\end{array}$ & Order \\
\hline $\begin{array}{l}\text { Joint audit investigates to ensure that the management does not } \\
\text { impose any restrictions on auditors with the aim of getting access } \\
\text { to information or people during the audit process. }\end{array}$ & 4.33 & 0.47 & 1 \\
\hline $\begin{array}{l}\text { The joint audit investigates to ensure rationality behind changing } \\
\text { previous auditors by the management }\end{array}$ & 1.72 & 0.44 & 13 \\
\hline All statements & 4.1538 & .80064 & \\
\hline
\end{tabular}

Results in Table 2 show that the general arithmetic mean of the relationship with related parties statement reached (4.1538) and a standard deviation of (.80064), where it's bigger than the test criteria of (3) out of (5) degrees. The overall level of the study sample respondents`responses was high and positive.

The statement stating that "the joint audit investigates to ensure that the management does not impose any restrictions on auditors with the aim of getting access to information or people during the audit process" ranked first in the study sample respondents' priorities and concerns with an arithmetic mean of (4.33) and standard deviation of (0.47), while the statement stating that "the joint audit investigates to ensure the rationality of the reasons behind changing previous auditors by the management" came last in the study sample respondents' concerns with an arithmetic mean of (1.72) and standard deviation of (0.44). Results shown in the above table indicate that there is an impact for the joint audit on each statement of the relationship with relevant parties' statement.

Table 3. Statement (company and financial industry)

\begin{tabular}{|c|c|c|c|}
\hline Statement (company and financial industry) & $\begin{array}{c}\text { Arithmetic } \\
\text { mean }\end{array}$ & $\begin{array}{l}\text { Standard } \\
\text { deviation }\end{array}$ & Order \\
\hline $\begin{array}{l}\text { The joint audit ascertains the financial position of the } \\
\text { company, its market activity and the demand for its products, } \\
\text { whether high or low, in the market. }\end{array}$ & 4.99 & 0.12 & 1 \\
\hline $\begin{array}{l}\text { The joint audit ascertains the company's competitive position } \\
\text { with other companies, its effectiveness, and whether it has an } \\
\text { impact on its declining profits, although the degree of } \\
\text { competition is high. }\end{array}$ & 1.72 & 0.45 & 11 \\
\hline All statements & 4.3636 & 92442. & \\
\hline
\end{tabular}

Results in Table 3 show that the general arithmetic mean of the relationship with related parties statement reached (4.3636) and a standard deviation of (.92442), where it's bigger than the test criteria of (3) out of (5) degrees. The overall level of the study sample respondents`responses was high and positive.

The statement which states that "the joint audits ascertains of the company`s financial situation, activity in the market and the up and down demand for its products in the market" ranked first in the study sample respondents 'priorities and interest with an arithmetic mean of (4.99) and standard deviation of (12), while the statement stating that "the joint audit ascertains the competitive status of the company with other companies, its effectiveness and impact on the decreasing of profits despite the high degree of competitiveness", "ranked last with an arithmetic mean of (1.72) and a standard deviation of (0.45). Results shown in the above table indicate that there is an impact for joint audit on each statement of the company and financial industry statements. 
Table 4. Statement (financial results and company`s operational processes)

\begin{tabular}{lccc}
\hline Statement (financial results and company`s operational processes) & $\begin{array}{c}\text { Arithmetic } \\
\text { mean }\end{array}$ & $\begin{array}{c}\text { Standard } \\
\text { deviation }\end{array}$ & Order \\
\hline $\begin{array}{l}\text { The joint audit ascertains the company's revenues and expenses } \\
\text { and any significant abnormal changes }\end{array}$ & 4.49 & 0.51 & 1 \\
\hline $\begin{array}{l}\text { The joint audit ascertains the profits made by the company and } \\
\text { compare these with other companies working in the same field. }\end{array}$ & 1.74 & 0.44 & 21 \\
\hline All statements & 4.4762 & .74960 \\
\hline
\end{tabular}

Results in Table 4 show that the general arithmetic mean of the relationship with related parties statement reached (4.4762) and a standard deviation of (.74960), where it's bigger than the test criteria of (3) out of (5) degrees. The overall level of the study sample respondents`responses was high and positive.

The statement which states that " the joint audit ascertains the company's revenues and expenses and any significant abnormal changes" ranked first in the study sample respondents priorities and interest with an arithmetic mean of (4.49) and standard deviation of (51.), while the statement stating that "the joint audit ascertains the profits made by the company and compare these with other companies working in the same field", "ranked last with an arithmetic mean of (1.74) and a standard deviation of (0.44). Results shown in the above table indicate that there is an impact for joint audit on each statement of the financial results and operational processes in the company.

Table 5 shows the arithmetic mean and standard deviation for each of the study statements as well as the relative significance order for the study sample respondents` responses on the impact of applying the joint audit to detecting fraud in financial statements.

Table 5. Statement

\begin{tabular}{lccc}
\hline Statement & $\begin{array}{c}\text { Arithmetic } \\
\text { mean }\end{array}$ & $\begin{array}{c}\text { Standard } \\
\text { deviation }\end{array}$ & Order \\
\hline Management and board of directors & 4.0833 & .77553 & 4 \\
\hline Relationship with relevant parties & 4.1538 & .80064 & 3 \\
\hline Company and financial industry & 4.3636 & .92442 & 2 \\
\hline Financial results and company`s operational processes & 4.4762 & .74960 & 1 \\
\hline
\end{tabular}

Table 5 has shown that financial results and operational processes in the company has ranked first in the study sample respondents` evaluation in the Jordanian audit offices, with an arithmetic mean amounting to(4.4762) and standard deviation of (74960.), while the management and board of directors proceeding ranked fourth has ranked first in the study sample respondents` evaluation with an arithmetic mean of (4.0833) and a standard deviation of (0.77553).

Results have indicated that all the calculated arithmetic means of the previous proceedings are greater than the test criterion (3) out of (5) degrees. These findings indicate that the evaluation of the study sample respondents comprising of auditors at Jordanian audit offices was high and positive.

\section{Hypotheses testing:}

Table 6

\begin{tabular}{ccccc}
\hline Model & R & R Square & Adjusted R Square & $\begin{array}{c}\text { Std. Error of the } \\
\text { Estimate }\end{array}$ \\
\hline $\begin{array}{c}\text { dimensi } \\
\text { on }\end{array}$ & 110a. & .012 & -072 & .8871. \\
\hline a. & Predictors: (Constant), A4, A3, A1, A2 & \\
\hline
\end{tabular}




\begin{tabular}{lllllll} 
Table & \multicolumn{3}{c}{7.} & ANOVA \\
\hline \begin{tabular}{lllllll} 
Model & & Sum of Squares & Df & Mean Square & F & Sig. \\
\hline 1 & Regression & 451. & 4 & 113. & 143. & $965 \mathrm{a}$. \\
\cline { 2 - 7 } & Residual & 36.991 & 47 & 787. & \\
\cline { 2 - 6 } & Total & 37.442 & 51 & & & \\
\hline
\end{tabular} \\
\hline
\end{tabular}

Table 6 and Table 7 above show the results of the simple linear regression analysis of the impact of joint audit on detecting and disclosing manipulation in financial statements from the point of view of auditors. It is found that the explanation ratio of the joint audit (R2) amounted to (012.) of the dependent variable discrepancy (detecting and disclosing fraud in the financial statements) is relatively low, and the $\mathrm{P}$ value derived from this relationship was 965 .) Which is greater than (5\%). According to these analysis results, the null main hypothesis, which states that "there is no statistically significant impact of joint audit on detecting manipulation in financial statements" is accepted whereas the alternative main hypothesis stating that " there is a statistically significant impact of joint audit on detecting fraud in financial statements from the point of view of auditors" is rejected.

\section{Conclusion}

The current study finding is no statistically significant impact of joint audit on detecting fraud in financial statements at the level (5\%) for all fraud detecting proceedings in the financial statements. The statistical tests explained a ratio (.012)of the dependent variable discrepancy (detecting fraud in financial statements) which is a relatively low explanation ratio and since the $\mathrm{P}$ value derived for this relationship amounted to (965) which is greater than (5\%), so the null hypotheses stating that there is no statistically significant impact of joint audit on the management and board of directors, the relationship with the relevant parties, and the company financial industry, the financial results and operational processes in the company in the detection of manipulation in financial statements. This may be due to operations executed by the management or to the fact that the management may have directed its employees to manipulate and forge information, thus making it difficult for the auditor to detect that. Auditors accepted such information as a proof of the credibility of data and information contained in financial statements, which were accepted as credible credentials. In addition to that, there is the possibility that the auditor may rely on another auditor to process the audit and as confirmed by Deng, et al. (2012), and this study conforms with (Deng et. al, 2012), and Haak, et al. (2018) regarding the non-observance of joint audit and relying more on the individual audit. The suggested recommendations:

- Observing individual audit in detecting fraud in financial statements since joint audit may result in problems among audit offices, which will have a negative impact on the audit process and the independence of the auditor.

- Observing individual audit in detecting fraud in financial statements since joint audit may limit audit evidence and auditors may rely on each other regarding data collection.

- Non-observance of the International Standard of Audit so auditors can achieve the desired aim of the audit process.

- Notifying about any fraud in financial statements to senior management levels in the company`s organizational structure, since this structure is higher than the administrative level of the people involved in fraud, Moreover, this makes it possible for auditors to overstep confidentiality which prevents auditors from reporting fraud in companies to regulatory and surveillance authorities.

\section{References}

AICPA. (2017). Audit guide: Audit sampling. John Wiley \& Sons.

Alfaraih, M., \& Alanez, F. (2012). The effectiveness of joint auditor requirements in promoting corporate disclosure quality. Arab Journal of Administrative Sciences, 19, 245-270.

Andre, et al.. (2016). Are Joint Audits Associated with Higher Audit Fees?. European Accounting Review, 2(25), 245-274. 
Asare, S. K., \& Wright, A. M. (2004). The effectiveness of alternative risk assessment and program planning tools in a fraud setting. Contemporary Accounting Research, 21(2), 325-352.

Bianchi, P., Falsetta, D., Minutti, M., \& Weisbrod, E. (2019). The Joint Audit Engagements and Client Tax Avoidance: Evidence from the Italian Statutory Audit Regime. The Journal of the American Taxation Association, 41, Spring, 31-58.

Carpenter, T- D. (2007). Audit team brainstorming, fraud risk identification, and fraud risk assessment: Implications of SAS No.99. The Accounting Review, 82(5), 1119-1140.

Deng, M., T. Lu, D., Simunic, A., \& Ye, M. (2012). Do joint audits improve or impair audit quality. Working paper, Baruch College, University of Houston, University of British Columbia and University of Toronto. 1-43.

Fernando, G. D., Abdel-Meguid, A. M., \& Elder, R. J. (2010). Audit quality attributes client size and cost of equity capital. Review of Accounting and Finance, 9(4), 363-381.

Haak, et al. (2018). Joint Audits: Does the Allocation of Audit Work Affect Audit Quality and Audit Fees?. Accounting in Europe, 15, 55-80.

Hijazi, Qutaiba, F., Abbadi, Sinan S., \& Al-Rahahleh, Ayat S. (2016). Corporate Governance Quality and Earnings Management: Evidence from Jordan. Australasian Accounting, Business and Finance Journal, 10(2).

Holm, C., \& Thinggaard, F. (2016). Paying for Joint or Single Audits? The Importance of Auditor Pairings and Differences in Technology Efficiency. International Journal of Auditing, 20, 16.

Ittonen, K., \& Trønnes, P. (2015, August). Benefits and Costs of Appointing Joint Audit Engagement Partners. Auditing: A Journal of Practice \& Theory American Accounting Association, 34, 23-46.

Kermiche, P. C. (2018). The Audit Market Dynamics in a Mandatory Joint Audit Setting: The French Experience. Journal of Accounting, Auditing \& Finance, 33(4), 463-484.

Krait, E., \& Hamedan, A. S. (2017). The role of joint audit in improving the accuracy of audit risk assessment In the Syrian business environment. Tishreen University Journal for Research and Scientific Studies-Economic and Legal Sciences Series, (33), 243-255.

Krait, E., Hamedan, A., \& Safi, H. (2018). The role of the joint audit in raising the efficiency of statistical sampling in auditing (A field study in the Syrian business environment). Tishreen University Journal for Research and Scientific Studies-Economic and Legal Sciences Series, 1(40), 101-114.

Porter, B., Simon, J., \& Hatherly, D. J. (2014). Principles of external auditing (4th ed.). Chichester: Wiley.

Zerni, M., Haapamaki, E., Ravinen, T., \& Nieml, L. (2012, December). Do Joint Audits Improve Audit Quality? Evidence from Voluntary Joint Audits. European Accounting Review, 21(4), 731-765.

\section{Websites}

http://jacpa.org.jo/ar-jo/

https://www.ammanchamber.org.jo/node/news.aspx ?id=3181\&lang=ar

https://www.ifac.org/system/files/downloads/a012-2010-iaasb-handbook-isa-240.pdf 